\title{
LEFTY2 Controls Migration of Human Endometrial Cancer Cells via Focal Adhesion Kinase Activity (FAK) and miRNA-200a
}

\author{
Nour Alowayed $\quad$ Madhuri S. Salker ${ }^{a, b} \quad$ Ni Zeng ${ }^{a, c, d} \quad$ Yogesh Singh $^{a} \quad$ Florian Lang ${ }^{a}$ \\ aDepartment of Cardiology, Vascular Medicine and Physiology, Eberhard-Karls-University of Tuebingen, \\ Tuebingen, 'Department of Women's Health, Eberhard Karls University of Tuebingen, Germany; 'State \\ Key Laboratory of Oral Diseases and Department of Cleft Lip and Palate Surgery, West China Hospital \\ of Stomatology, Sichuan University, Chengdu, PR China
}

\section{Key Words}

E-cadherin • miR-200a • FAK • Migration • Tumor cells

\begin{abstract}
Background: LEFTY2, a suppressor of cell proliferation, tumor growth, regulator of stemness and embryonic differentiation, is a negative regulator of cancer cell reprogramming. Malignant transformation may lead to migration requiring loss of adhesion and gain of migratory activity. Signaling involved in the orchestration of migration, proliferation and spreading of cells include focal adhesion kinase (FAK) and adhesion molecule E-cadherin. Aims: The present study explored whether LEFTY2 influences the proliferation marker MKi67, FAK activity, E-cadherin abundance and migration of Ishikawa human endometrial carcinoma cells. Moreover, the study explored the involvement of microRNA-200a (miR-200a), which is known to regulate cellular adhesion by targeting E-Cadherin. Methods: FAK activity was estimated from FAK phosphorylation quantified by Western blotting, migration utilizing a wound healing assay, miR-200a and MKi67 expression levels utilizing qRT-PCR, cell proliferation and apoptosis using BrdU and Annexin V staining, respectively, and E-Cadherin (E-Cad) abundance, using confocal microscopy. Results: LEFTY2 (25 ng/ml, 48 hours) treatment was followed by decrease of MKi67 expression, FAK activity and migration. LEFTY2 upregulated miRNA-200a and E-Cad protein level in Ishikawa cells. The effect of LEFTY2 on migration was mimicked by FAK inhibitor PF $573228(50 \mu \mathrm{M})$. Addition of LEFTY2 in the presence of PF-573228 did not result in a further significant decline of migration. Conclusion: In conclusion, LEFTY2 downregulates MKi67 expression and FAK activity, up-regulates miR-200a and E-cadherin, and is thus a powerful negative regulator of endometrial cell proliferation and migration.
\end{abstract}

N. Alowayed and M.S. Salker contributed equally and thus share first authorship.

Florian Lang, MD

KARGER
Departments of Physiology, Cardiology and Vascular Medicine,

University of Tuebingen, Gmelinstr. 5, 72076 Tuebingen (Germany)

Tel. +49 7071 29-72194, Fax +49 7071 29-5618, E-Mail florian.lang@uni-tuebingen.de 


\section{Cellular Physiology Cell Physiol Biochem 2016;39:815-826 and Biochemistry Published online: August 09, $2016 \quad \begin{aligned} & \text { DOI: } 2016 \text { The Author(s). Published by S. Karger AG, Basel } \\ & \text { www.karger.com/cpb }\end{aligned}$ \\ Alowayed et al.: Lefty2 Sensitive Endometrial Cancer Cell Migration}

\section{Introduction}

LEFTY2, also called endometrial bleeding-associated factor (EBAF), is a recently discovered member of the transforming growth factor (TGF)- $\beta$ family $[1,2]$. Human LEFTY2 is secreted as a $42-\mathrm{kDa}$ precursor susceptible to proteolytic cleavage. LEFTY2 active forms are able to induce mitogen-activated protein kinase activity and to inhibit TGF- $\beta$ signaling [3].

LEFTY2 expression is low in healthy endometrium, but its expression levels are increased prior to or during menstrual bleeding [4]. Enhanced LEFTY2 expression is associated with infertility [4] and abnormal uterine bleeding [5, 6]. The biological consequence of this overexpression remains to be determined. LEFTY2 also participates in the regulation of stemness and embryonic differentiation [7-19], reprogramming cancer cells [20] and suppression of tumor cells [21-24].

Recent evidence indicates that cancer cells retain many of the same characteristics as stem cells. An in depth understanding of the mechanisms that control stemness may lead to a better understanding of cancer cells. Several recent reports have revealed that embryonic stem (ES) cells are also found in many cancers, suggesting that these shared features may provide clues to designing cancer therapies $(1,2)$. A clue pointing to this shared feature is Nodal-LEFTY2 signaling. LEFTY is a critical regulator of very early human ES cell fate decisions, as LEFTY negatively modulates Nodal/TGF- $\beta$ signaling, a key factor in the maintenance of pluripotency in human ES cells. Nodal and its coreceptor Cripto is expressed highly in certain malignant melanoma cells, and their malignant properties can be inhibited by LEFTY $[25,26]$. LEFTY2 can inhibit cell proliferation, stimulate apoptosis and thus suppress tumor growth [20, 27-29], which can be quantified from expression of the proliferation marker Ki-67 (MKi67) [30].

A previous study demonstrated that LEFTY2 modulates migration [31]. Signaling contributing to the regulation of migration includes Focal adhesion kinase (FAK) [32-36], a ubiquitously expressed protein tyrosine kinase with an amino acid sequence about $90 \%$ homologous between humans, chickens, mice and frogs [37]. Lethality of FAK-deficient embryos at E8.5 suggests that it is critical during mammalian development [38]. FAK is further a powerful regulator of cell stiffness, proliferation and survival [39]. Abnormally high expression of FAK activity is associated with invasion and metastasis of cancer cells as well as tumor angiogenesis [37, 39]. Migration is inhibited by adhesion molecule E-Cadherin [40]. E-Cadherin is up-regulated by miR-200a [41], a powerful regulator of malignant transformation [42].

The present study explored whether LEFTY2 affects FAK activity, miR-200a, E-Cadherin and migration of human endometrial cancer cells.

\section{Materials and Methods}

\section{Cell Culture}

Ishikawa cells, a well differentiated endometrial carcinoma cell model [43, 44], were cultured in DMEM/F12 without phenol red, containing 10\% fetal calf serum (FCS), 1\% antibiotic/antimycotic solution and $0.25 \%$ L-Glutamine (Invitrogen, Karlsruhe, Germany). Cells were treated as described with recombinant human LEFTY2 (25 ng/ml; 746-LF-025/CF) (R\&D Systems, Oxford, UK) and/or FAK inhibitor PF-573228 $(50 \mu \mathrm{M})$ (TOCRIS bioscience, Wiesbaden-Nordenstadt, Germany) for 48 hours.

Quantitative Real-time PCR (qRT-PCR)

Total RNA was extracted from Ishikawa cultures using Trizol (Invitrogen) based on a phenolchloroform extraction protocol [45]. Equal amounts of total RNA ( $2 \mu \mathrm{g}$ ) were reverse transcribed by using the Superscript III First-Strand synthesis system for RT-PCR (Invitrogen) using an oligo dT primer. The resulting first-strand cDNA was diluted and used as template in qRT-PCR experiments. L19 was used as housekeeping gene to normalize for variances in input cDNA. Detection of gene expression was performed with KappaFast 


\section{Cellular Physiology Cell Physiol Biochem 2016;39:815-826

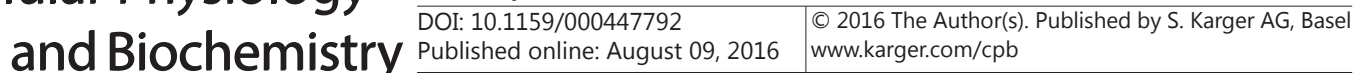 \\ Alowayed et al.: Lefty2 Sensitive Endometrial Cancer Cell Migration}

-SYBR Green (Peqlab, Erlangen, Germany) and Quantitative RT-PCR was performed on a BioRad iCycler iQ ${ }^{\mathrm{TM}}$ Real-Time PCR Detection System (Bio-Rad Laboratories, München, Germany). The expression levels of the samples are provided as arbitrary units defined by the $\Delta \Delta \mathrm{C}_{\mathrm{T}}$ method. All measurements were performed in triplicate. Melting curve analysis confirmed amplification specificity.

$\begin{array}{ll}\text { MKi67 } & \text { forward (5'-3'): CACACTCCACCTGTCCTGAA } \\ & \text { reverse (5'-3'): GACTAGGAGCTGGAGGGCTT } \\ \text { L19 } & \text { forward (5'-3'): GCAGCCGGCGCAAA } \\ & \text { reverse (5'-3'): GCGGAAGGGTACAGCCAAT }\end{array}$

miRNAs Quantitative Real-time PCR (miR-qRT-PCR)

Total RNA including miRNAs was extracted from Ishikawa cultures using miRNeasy Kit (Qiagen, Duesseldorf, Germany) as described previously [46]. Equal amounts of total RNA (100ng) were reverse transcribed by using the miRNA universal cDNA synthesis kit II (Exiqon, Vedbaek, Denmark) and PCR reaction was set using miR-200a-LNA ${ }^{\mathrm{mm}}$ primers (Exiqon, Vedbaek, Denmark) [46]. Detection of miRNA was performed with KappaFast-SYBR Green (Peqlab, Erlangen, Germany) and miR-qRT-PCR was performed on a BioRad iCycler iQ ${ }^{\mathrm{TM}}$ Real-Time PCR Detection System (Bio-Rad Laboratories, München, Germany). The transcript levels of the samples were expressed as arbitrary units defined by the $\Delta \Delta \mathrm{C}_{\mathrm{T}}$ method. All measurements were performed in triplicate. Melting curve analysis confirmed amplification specificity.

\section{BrdU staining}

The BrdU staining was performed as recommended by the manufacturers' protocol with slight modification (eBioscience). In brief, Ishikawa cells were treated in 6-well plate as described above. Two hours prior to harvesting the cells BrdU $(10 \mu \mathrm{M})$ was added into the medium. The supernatant was removed and $250 \mu \mathrm{l}$ of warm trypsin was added to the plate and returned to the incubator. After detachment, the cells were transferred to $15 \mathrm{ml}$ tubes and warm PBS was added up to $10 \mathrm{ml}$. The tubes were then centrifuged at $300 \mathrm{xg}$ for $5 \mathrm{~min}$ at room temperature. The supernatant was removed and $200 \mu \mathrm{l}$ PBS was added to the cell pellet. The resuspended cells were transferred to 96-well plate and centrifuged at 300xg room temperature for $5 \mathrm{~min}$. The supernatant was removed and $200 \mu \mathrm{l}$ of Fixation buffer (eBioscience) was added and incubated at room temperature for 15 minutes, protected from light. After incubation, the plate was centrifuged at $300 \mathrm{xg}$ at room temperature for $5 \mathrm{~min}$ then washed twice with staining buffer. $25 \mu \mathrm{l}$ DNase I was added to $75 \mu \mathrm{l}$ of staining buffer and incubated at $37^{\circ} \mathrm{C}$ for 1 hour, protected from light. The cells were washed twice with the staining buffer. For intracellular staining, $2 \mu \mathrm{l}$ BrdU antibody was added and mixed gently and incubated at room temperature for 30 minutes in the dark. Then centrifuged at 300xg at room temperature for $5 \mathrm{~min}$ and then $200 \mu \mathrm{l}$ of PBS was added to each sample and transferred to FACS tubes for analysis. All the FACS were analysed by Flowjo software (Treestar, USA).

\section{Annexin V staining}

The Annexin V staining was performed as recommended by manufacturer (eBioscience). Cells were washed once with $200 \mu \mathrm{l}$ of PBS, and once with $1 \mathrm{X}$ binding buffer. Then cells were suspended in $150 \mu \mathrm{l}$ of 1 $\mathrm{X}$ binding buffer and $2 \mu \mathrm{l}$ of fluorochrome-conjugated Annexin $\mathrm{V}$ was added. The plate was incubated for 15 minutes at room temperature, protected from the light. Wash cells with $1 \mathrm{X}$ binding buffer and resuspended in $200 \mu \mathrm{l} 1 \mathrm{X}$ binding buffer then the cells were transferred to FACS tubes, and $2 \mu \mathrm{l}$ of Propidium Iodide (PI; Sigma) was added. The samples were analyzed with flow cytometry within 4 hours. All the FACS were analysed by Flowjo software (Treestar, USA).

\section{Western blotting}

Whole-cell protein extracts were obtained by direct lysis in Laemmli buffer heated to $95{ }^{\circ} \mathrm{C}$. Proteins were separated on SDS-polyacrylamide gels and transferred to PVDF membranes [47]. The membranes were incubated overnight at $4{ }^{\circ} \mathrm{C}$ with anti-phospho-FAK (Tyr397) antibody (\#8556), anti-total FAK antibody (A-17;\#13309) or anti GAPDH antibody (1:1000; \#2118, Cell Signaling, Leiden, The Netherlands), and then with secondary anti-rabbit HRP-conjugated antibody (1:2000; Cell Signaling) for 1 hour at room temperature. Following incubation with HRP-conjugated secondary antibodies the chemiluminescence was 


\section{Cellular Physiology Cell Physiol Biochem 2016;39:815-826 \begin{tabular}{cl|l} 
DOI: 10.1159/000447792 & O 2016 The Author(s). Published by S. Karger AG, Basel \\
www.karger.com/cpb
\end{tabular} \\ Alowayed et al.: Lefty2 Sensitive Endometrial Cancer Cell Migration}

visualized using the Novex ECL ${ }^{+}$kit (Novex® ECL, Invitrogen). Densitometry was performed on scanned immunoblot images using the ImageJ gel analysis tool.

\section{Confocal microscopy}

Cells were treated and grown in sterile 4-well tissue culture chambers (Sarstedt,Germany). They were washed with ice-cold PBS once and then fixed in 4\% paraformaldehyde (PFA) for 15 minutes at room temperature. Cells were washed $3 \mathrm{x}$ with ice-cold PBS, and permeabilised with $1 \mathrm{x}$ permeabilization buffer (eBioscience) for 15 minutes at room temperature. E-Cadherin primary antibody (\#3195; Cell Signaling) [diluted in permeabilization buffer (1:100)] was added and kept in a humidified chamber at $4^{\circ} \mathrm{C}$ overnight. The following day, cells were washed with ice-cold PBS (x4) and incubated with the secondary antibody goat anti-rabbit IgG-FITC (\#sc-2012; Santa Cruz Biotechnology) (1:200) for 1hour at room temperature. The chambers were then washed three times with ice-cold PBS. Then DRAQ5 ${ }^{\mathrm{TM}}$ (nuclear stain; eBioscience) was added. To mount Ishikawa cells CC/Mount (Sigma) was added and the cover slip was placed. Confocal microscopy was performed with a confocal laser-scanning microscope (LSM 5 Exciter, Carl Zeiss, Germany) with a C-Apochromat 63/1.3 NA DIC water immersion objective. (Carl Zeiss, Germany)

\section{Migration assays}

Ishikawa cells were counted and seeded in sterile 6 well plates and grown to confluence. Each well was scratched with a sterile $10 \mu \mathrm{l}$ pipette tip, washed with PBS, and placed into fresh medium and treated as described. The sites at which wounds were to be measured were marked on the undersurface of wells to ensure that measurements were made at the same place. Wound width was measured by phase-contrast microscopy (Nikon Diaphot 300, Amsterdam, The Netherlands) immediately and after $48 \mathrm{~h}$. Data were acquired with Bresser Mikrocam (Bresser GmbH, Rhede, Germany) camera using MikroCamLab software and analysed with ImageJ software. Wound closure was calculated and expressed as a percentage of the initial wound width as described previously [48]. The data shown represent the means \pm SEM of 3 measurements from 3 or more independent experiments.

\section{Statistics}

Data are provided as means \pm SEM, $n$ represents the number of independent experiments. All data were tested for significance using Student's unpaired two-tailed $t$-test and only results with $P<0.05$ were considered statistically significant.

\section{Results}

The present study explored effects of LEFTY2 on proliferation and migration of human endometrial cancer (Ishikawa) cells. To this end, confluent cultures of Ishikawa cells were treated with $25 \mathrm{ng} / \mathrm{ml}$ of recombinant LEFTY2 for 48 hours. As illustrated in Fig. 1A, LEFTY2 significantly decreased the transcript levels of the proliferation marker MKi67. To investigate the effect of LEFTY2 during cell proliferation on Ishikawa cells BrdU assay was implemented. As shown in Fig. 1B, the proliferative ability of cells was significantly decreased (34\%) after a $48 \mathrm{~h}$ treatment with LEFTY2.

In order to test whether LEFTY2 affects migration, a wound-healing assay was performed. To this end, confluent Ishikawa cells were treated by mechanical wounding and subsequently treated with or without LEFTY2 $(25 \mathrm{ng} / \mathrm{ml})$ for 48 hours. Wound widths were measured immediately $(0 \mathrm{~h})$ and after $48 \mathrm{~h}$, and the percentage of wound closure was determined (Fig. 2A, B). Wound closure in the LEFTY2 treated cells was significantly reduced compared to the controls. Therefore, a significant decrease in cell reconstitution/migration was observed when recombinant LEFTY2 was added.

A further series of experiments explored whether the effect of LEFTY2 on migration was paralleled by an influence on the activity of focal adhesion kinase (FAK). To this end, confluent cultures of Ishikawa cells were treated with $25 \mathrm{ng} / \mathrm{ml}$ of recombinant LEFTY2 for 48 hours and total protein lysates harvested for Western blot analysis. FAK activity was quantified from FAK-phosphorylation (Tyr397), utilizing a specific antibody. Total FAK levels 
A

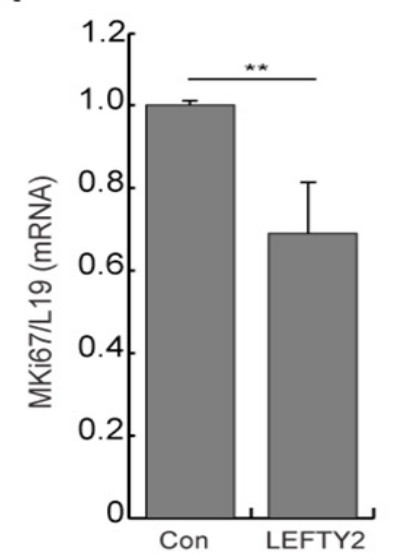

B

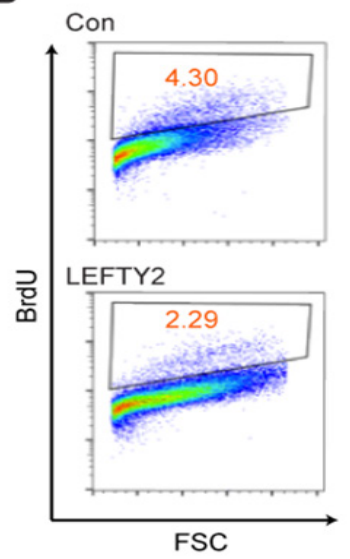

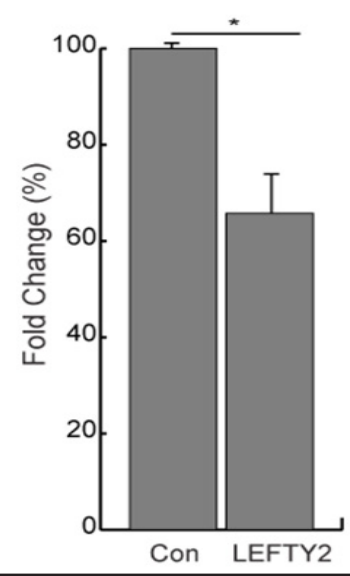

Fig. 1. Effect of LEFTY2 on proliferation marker MKi67 in Ishikawa cells. A. Arithmetic means \pm SEM ( $n=4$, arbitrary units) of MKi67 transcript levels. B. Original FACS plot of BrdU staining (\% of proliferative cells). C. Fold Change $\left(\% \pm\right.$ SEM) of cell proliferation $(\mathrm{n}=4) . *(P<0.05),{ }^{* *}(P<0.01)$ indicates statistically significant difference, Student's t-test.

Fig. 2. Effect of LEFTY2 treatment on migration of Ishikawa cells. A. Original photographs illustrating migration of human endometrial cancer Ishikawa cells in the absence (left panels) and presence (right panels) of LEFTY2 $(25 \mathrm{ng} / \mathrm{ml})$ in a wound-healing assay at 0 hours (upper panels) and 48 hours (lower panels) after wounding. B. Arithmetic means \pm SEM $(n=10)$ of the percentage of wound closure determined by image analysis in the absence and presence of LEFTY2 $(25 \mathrm{ng} / \mathrm{ml}) .{ }^{* *}(P<0.01)$ indicates statistically significant difference, Student's t-test.

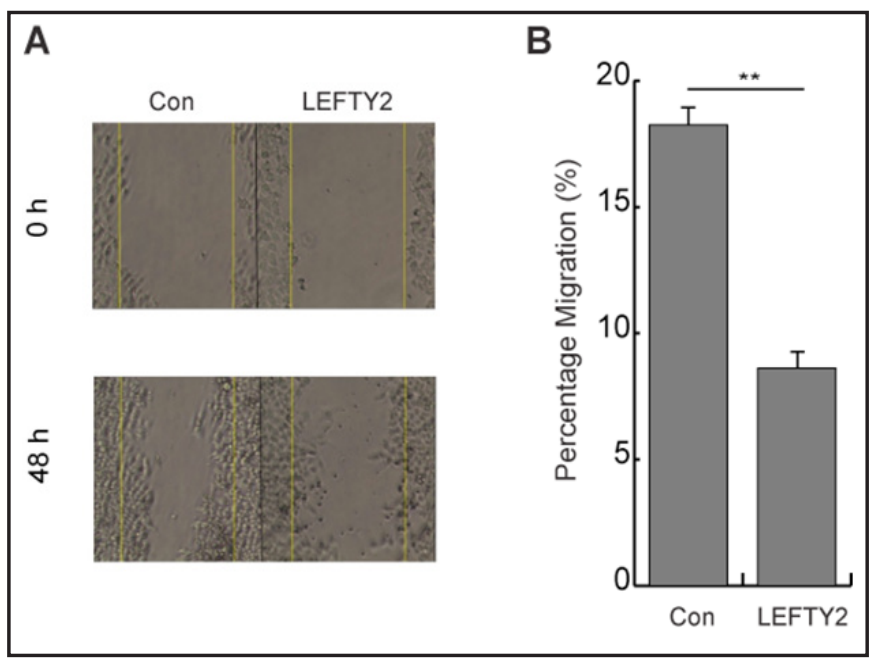

Fig. 3. Effect of LEFTY2 on focal adhesion kinase (FAK) phosphorylation in Ishikawa cells. A. Representative original Western blots showing phosphorylated-FAK (Tyr397), total FAK and GAPDH protein abundance in human endometrial cancer Ishikawa cells after 48 hours culture in the absence or presence of LEFTY2 (25ng/ml). B. Arithmetic means \pm SEM ( $n=4$, arbitrary units) of phosphorylated-FAK/total FAK protein ratio normalized to GAPDH in Ishikawa cells after 48 hours culture in the absence or presence of LEFTY2 (25ng/ml). ${ }^{* *}(P<0.01)$ indicates statistically significant difference using Student's $t$-test.

remained unchanged. As illustrated in Fig. 3A, B, treatment of Ishikawa cells with LEFTY2 was followed by a significant decrease of FAK phosphorylation pointing to a decrease of FAK activity. 


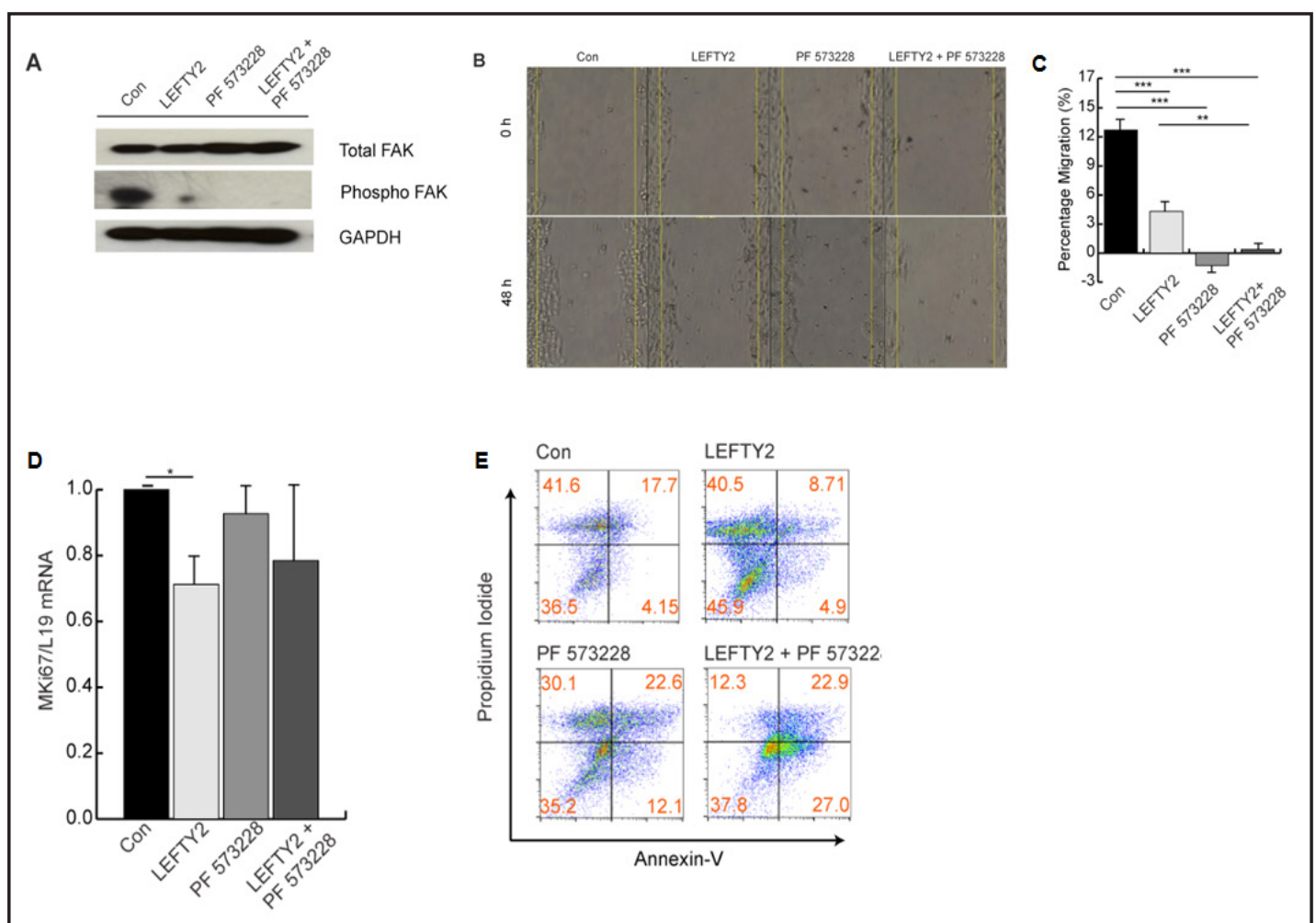

Fig. 4. Effect of FAK inhibition on migration, proliferation and apoptosis of Ishikawa cells. A. Representative original Western blots showing phosphorylated-FAK (Tyr397), total FAK and GAPDH protein abundance in human endometrial cancer Ishikawa cells after 48 hours culture in the absence or presence of LEFTY2 $(25 \mathrm{ng} / \mathrm{ml}) \pm$ FAK inhibitor PF $573228(50 \mu \mathrm{M})$. B. Original photographs illustrating migration of human endometrial cancer Ishikawa cells in the absence and presence of LEFTY2 (25ng/ml), FAK inhibitor PF573228 alone $(50 \mu \mathrm{M})$ and LEFTY2 $(25 \mathrm{ng} / \mathrm{ml})$ together with FAK inhibitor PF $573228(50 \mu \mathrm{M})$ at 0 hours (upper panels) and 48 hours (lower panels) after wounding. C. Arithmetic means \pm SEM $(n=4)$ of the percentage of wound closure determined by image analysis in the absence and presence of LEFTY2 (25ng/ $\mathrm{ml})$, FAK inhibitor PF $573228(50 \mu \mathrm{M})$ and LEFTY2 $(25 \mathrm{ng} / \mathrm{ml})$ together with FAK inhibitor PF 573228 (50 $\mu \mathrm{M}) .{ }^{* *}(P<0.01),{ }^{* * *}(P<0.001)$ indicates statistically significant difference, Student's $t$-test. D. Human endometrial cancer Ishikawa cells in the absence and presence of LEFTY2 (25ng/ml), FAK inhibitor PF-573228 alone $(50 \mu \mathrm{M})$ and LEFTY2 $(25 \mathrm{ng} / \mathrm{ml})$ together with FAK inhibitor PF-573228 (50 $\mu \mathrm{M})$ for 48 hours. Expression levels of MKi67 were measured using qRT-PCR. ${ }^{*} P<0.05$ indicate statistically significant difference, Student's $t$-test. E. In parallel experiments cells were subjected to Propidium Iodide (PI) and Annexin-V staining. Original FACS plots shown.

In additional experiments Ishikawa cells were treated for 48 hours with LEFTY2 (25 ng/ ml) either with or without FAK inhibitor PF 573228 or left untreated (control). Cell lysates were subjected to Western blot analysis to assess levels of total FAK and phosphorylated FAK (Tyr397). As shown in Fig. 4A, there was a significant reduction in phospho-FAK in cells treated with LEFTY2 with or without inhibitor PF 573228, compared to the control. No change was observed in total FAK levels.

A next series of experiments determined whether inhibition of FAK phosphorylation was paralleled by inhibition of migration. To this end, a wound-healing assay was performed on Ishikawa cells treated with LEFTY2 $(25 \mathrm{ng} / \mathrm{ml})$ with or without PF-573228 or control cells. As shown in Fig. 4B and C, the percentage of wound closure was significantly decreased by a 48 hours treatment with FAK inhibitor PF 573228, which thus fully mimicked the effect of LEFTY2 on migration. The additional presence of LEFTY2 did not lead to a further significant decrease of migratory activity, indicating that LEFTY2 was effective in large part 


\section{Cellular Physiology Cell Physiol Biochem 2016;39:815-826

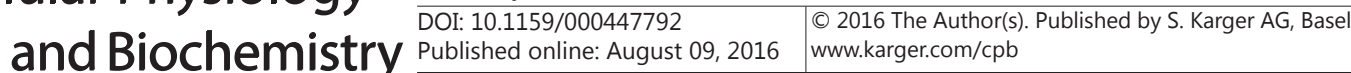

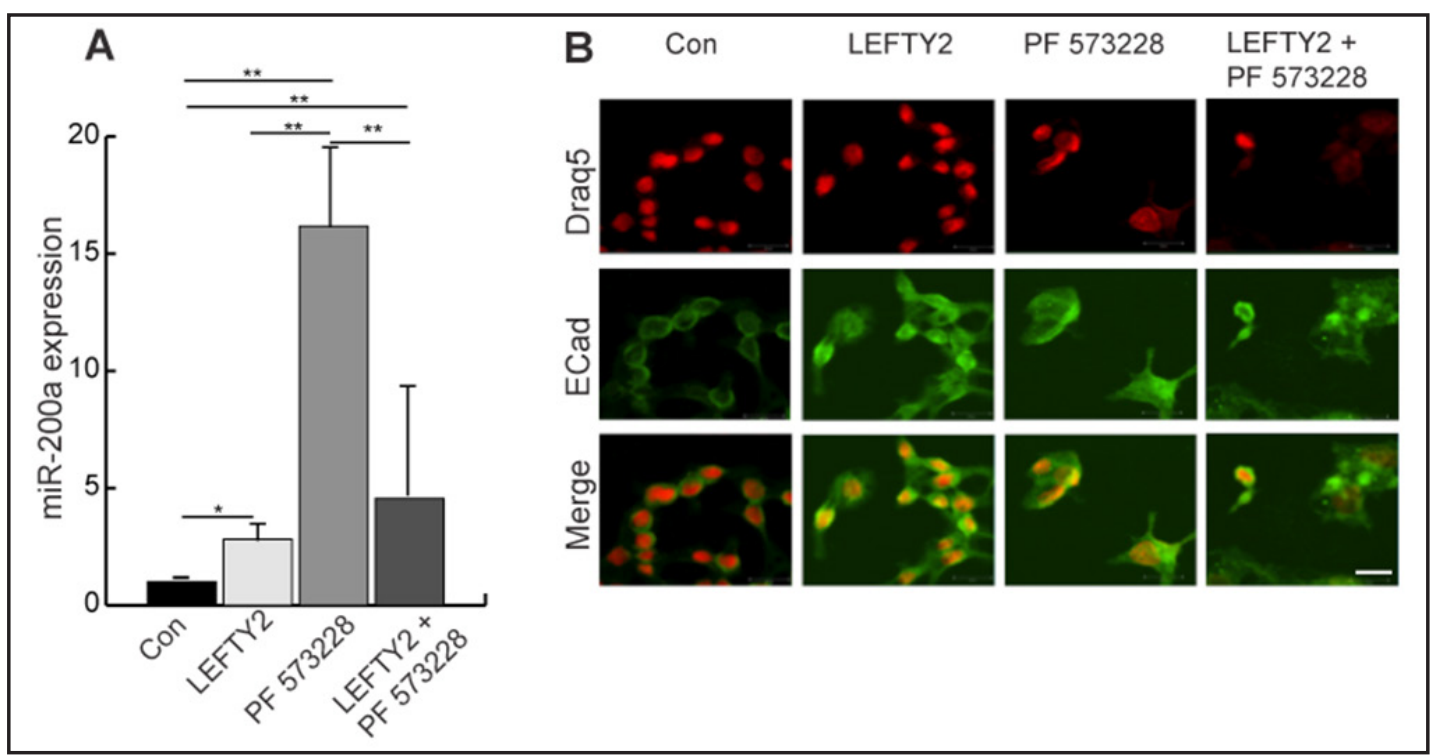

Fig. 5. Effect of LEFTY2 treatment on miR-200a and E-Cadherin in Ishikawa cells. A. Human endometrial cancer Ishikawa cells in the absence and presence of LEFTY2 (25ng/ml), FAK inhibitor PF-573228 alone (50 $\mu \mathrm{M})$ and LEFTY2 $(25 \mathrm{ng} / \mathrm{ml})$ together with FAK inhibitor PF $573228(50 \mu \mathrm{M})$ for 48 hours. Expression levels of miR-200a/5S rRNA were measured using qRT-PCR. B. Confocal Images of E-Cadherin (E-Cad) with and without LEFTY2 treatment in the presence or absence of FAK inhibitor PF573228 (50 $\mu \mathrm{M})$. Green (E-Cad), Red (Draq5; nucleus). ${ }^{*} P<0.05,{ }^{* *} P<0.01$ indicate statistically significant difference, Student's $t$-test.

by inhibiting FAK. To investigate if the effect of LEFTY2 on migration was dependent upon cell proliferation we performed qPCR for MKi67. As illustrated in Fig. 4D and E, treatment with LEFTY2 again decreased MKi67 transcript levels. However treatment with the FAK inhibitor slightly decreased MKi67 levels, though not reaching statistical significance. FAK inhibitor PF 573228 treated cells showed a slight increase in apoptotic cells.

We further explored the possibility that LEFTY2 treatment can influence the expression of E-Cadherin and of miR-200a. Ishikawa cells either remained untreated or were treated with LEFTY2 (25ng/ml) with or without the FAK inhibitor PF-573228 for a total of 48 hours. As showed in Fig. 5A, miR-200a was significantly upregulated in LEFTY2, PF-573228 and LEFTY2+ PF 573228 treated cells compared to the control. In parallel cultures, confocal microscopy revealed that LEFTY2 with or without PF-573228 treatment further increased E-Cadherin protein abundance (Fig. 5B).

\section{Discussion}

The present study uncovers a powerful inhibitory effect of LEFTY2 on the activity of FAK. FAK is a component of focal adhesions considered as a point of convergence of integrin and growth factor mechanical signaling $[39,49]$. FAK is important for maintaining cell rigidity (stiffness) through promoting a static and highly aligned contractile cytoskeleton $[50,51]$. It is a powerful regulator of actin polymerization and distribution of microfilaments [52] by activating downstream molecules such as: PI3-K [53-55], PAK1 [56, 57], Nhe1 [58, 59], rho kinase [38, 60, 61] or Src [62]. In FAK-deficient cells, reduced cytoskeletal stability is attributed to a compensatory increase of rhoA-kinase and ROCK activity [38, 60, 63]. Further, FAK directly interacts with multiple cell surface receptors and signaling proteins $[39,60,62,64]$ thus mediating a variety of physiological responses. Therefore, by regulating the activity of FAK, LEFTY2 could contribute to regulation of other physiological processes beyond regulating actin polymerization and cell stiffness [65].

\section{KARGER}




\section{Cellular Physiology Cell Physiol Biochem 2016;39:815-826 \begin{tabular}{cl|l} 
DOI: 10.1159/000447792 & O 2016 The Author(s). Published by S. Karger AG, Basel \\
and Biocherger.com/cpb
\end{tabular} \\ Alowayed et al.: Lefty2 Sensitive Endometrial Cancer Cell Migration}

As a regulator of focal adhesion dynamics, FAK is a critical mediator of signaling events between cells and their extracellular matrix. Up-regulation of FAK was seen in both endometrial hyperplasia and carcinoma, implying that FAK may play an important role in epithelial-mesenchymal transition (EMT) [66-71] and migration [32-36] during endometrial carcinogenesis [72]. According to our results both, LEFTY2 and PF 573228, decrease phosphorylation of FAK, an observation pointing to inactivation of FAK [73]. Deletion or inhibition of FAK impairs migration of fibroblasts [74]. Thus, treatment with LEFTY2 or PF573228 decreases migration of Ishikawa cells. LEFTY2 could counteract migration by downregulating microRNA miR-200a, a powerful stimulator of E-Cadherin expression $[75,76]$.

By supporting adhesion LEFTY2 counteracts detachment of cells from adjacent cells, thus suppressing migration and metastasis of tumor cells. LEFTY2 may further influence migration by down-regulation of the $\mathrm{Na}^{+} / \mathrm{H}^{+}$exchanger [77], a carrier participating in the machinery of cell migration [78-84]. The molecular link between signaling and migration was recently described in colon cancer cells [85]. LEFTY2 may further be effective by downregulation of FAK/phosphatidylinositol-3-kinase/Akt signaling, which is followed by actin reorganization controlling the migratory potential of tumor cells [65, 85]. By whatever mechanism, LEFTY2 does not only counteract tumor growth but as well as the migration of tumor cells and thus presumably tumor metastasis. Clearly, further investigations are required to fully uncover the pleotropic effects of this interesting mediator on tumor cells.

In conclusion, LEFTY2 treatment of human endometrial carcinoma cells down-regulates the activity of the FAK and up-regulates E-Cadherin. LEFTY2 is thus a powerful inhibitor of Ishikawa cell migration.

\section{Acknowledgements}

This work was supported by grants from Deutsche Forschungsgemeinschaft, Open Access Publishing Fund of Tuebingen University (F.L.) and the EMBO Long Term Postdoctoral fellowship (ATLF 20-2013 to M.S.S). The authors gratefully acknowledge the meticulous preparation of the manuscript by Tanja Loch and Lejla Subasic.

\section{Disclosure Statement}

The authors state that they have no conflict of interest.

\section{References}

1 Cornet PB, Picquet C, Lemoine P, Osteen KG, Bruner-Tran KL, Tabibzadeh S, Courtoy PJ, Eeckhout Y, Marbaix E, Henriet P: Regulation and function of lefty-a/ebaf in the human endometrium. Mrna expression during the menstrual cycle, control by progesterone, and effect on matrix metalloprotineases. J Biol Chem 2002;277:42496-42504.

2 Ulloa L, Tabibzadeh S: Lefty inhibits receptor-regulated smad phosphorylation induced by the activated transforming growth factor-beta receptor. J Biol Chem 2001;276:21397-21404.

3 Ulloa L, Creemers JW, Roy S, Liu S, Mason J, Tabibzadeh S: Lefty proteins exhibit unique processing and activate the mapk pathway. J Biol Chem 2001;276:21387-21396.

4 Salker MS, Christian M, Steel JH, Nautiyal J, Lavery S, Trew G, Webster Z, Al-Sabbagh M, Puchchakayala G, Foller M, Landles C, Sharkey AM, Quenby S, Aplin JD, Regan L, Lang F, Brosens JJ: Deregulation of the serum- and glucocorticoid-inducible kinase sgk1 in the endometrium causes reproductive failure. Nat Med 2011;17:1509-1513. 


\section{Cellular Physiology Cell Physiol Biochem 2016;39:815-826 \begin{tabular}{l|l|l|}
\hline DOI: 10.1159/000447792 & $\begin{array}{l}\text { C) 2016 The Author(s). Published by S. Karger AG, Basel } \\
\text { www.karger.com/cpb }\end{array}$
\end{tabular} \\ Alowayed et al.: Lefty2 Sensitive Endometrial Cancer Cell Migration}

5 Kothapalli R, Buyuksal I, Wu SQ, Chegini N, Tabibzadeh S: Detection of ebaf, a novel human gene of the transforming growth factor beta superfamily association of gene expression with endometrial bleeding. J Clin Invest 1997;99:2342-2350.

6 Tabibzadeh S, Kothapalli R: From steroid signals to local regulatory factors involved in endometrial bleeding. Eur J Obstet Gynecol Reprod Biol 1996;70:25-27.

7 Branford WW, Essner JJ, Yost HJ: Regulation of gut and heart left-right asymmetry by context-dependent interactions between xenopus lefty and bmp4 signaling. Dev Biol 2000;223:291-306.

8 Branford WW, Yost HJ: Lefty-dependent inhibition of nodal- and wnt-responsive organizer gene expression is essential for normal gastrulation. Curr Biol 2002;12:2136-2141.

9 Branford WW, Yost HJ: Nodal signaling: Crypticlefty mechanism of antagonism decoded. Curr Biol 2004;14:R341-343.

10 Essner JJ, Branford WW, Zhang J, Yost HJ: Mesendoderm and left-right brain, heart and gut development are differentially regulated by pitx2 isoforms. Development 2000;127:1081-1093.

11 Freemantle SJ, Kerley JS, Olsen SL, Gross RH, Spinella MJ: Developmentally-related candidate retinoic acid target genes regulated early during neuronal differentiation of human embryonal carcinoma. Oncogene 2002;21:2880-2889.

12 Izraeli S, Lowe LA, Bertness VL, Good DJ, Dorward DW, Kirsch IR, Kuehn MR: The sil gene is required for mouse embryonic axial development and left-right specification. Nature 1999;399:691-694.

13 Postovit LM, Costa FF, Bischof JM, Seftor EA, Wen B, Seftor RE, Feinberg AP, Soares MB, Hendrix MJ: The commonality of plasticity underlying multipotent tumor cells and embryonic stem cells. J Cell Biochem 2007;101:908-917.

14 Tabibzadeh S, Hemmati-Brivanlou A: Lefty at the crossroads of "stemness" and differentiative events. Stem Cells 2006;24:1998-2006.

15 Wilting J, Hagedorn M: Left-right asymmetry in embryonic development and breast cancer: Common molecular determinants? Curr Med Chem 2011;18:5519-5527.

16 Yost HJ: Establishment of left-right asymmetry. Int Review Cytol 2001;203:357-381.

17 Blum M, Schweickert A, Vick P, Wright CV, Danilchik MV: Symmetry breakage in the vertebrate embryo: When does it happen and how does it work? Dev Biol 2014;393:109-123.

18 Neugebauer JM, Yost HJ: Fgf signaling is required for brain left-right asymmetry and brain midline formation. Dev Biol 2014;386:123-134.

19 Rosa A, Papaioannou MD, Krzyspiak JE, Brivanlou AH: Mir-373 is regulated by tgfbeta signaling and promotes mesendoderm differentiation in human embryonic stem cells. Dev Biol 2014;391:81-88.

20 Cavallari C, Fonsato V, Herrera MB, Bruno S, Tetta C, Camussi G: Role of lefty in the anti tumor activity of human adult liver stem cells. Oncogene 2013;32:819-826.

21 Malchenko S, Galat V, Seftor EA, Vanin EF, Costa FF, Seftor RE, Soares MB, Hendrix MJ: Cancer hallmarks in induced pluripotent cells: New insights. J Cell Physiol 2010;225:390-393.

22 Papageorgiou I, Nicholls PK, Wang F, Lackmann M, Makanji Y, Salamonsen LA, Robertson DM, Harrison CA: Expression of nodal signalling components in cycling human endometrium and in endometrial cancer. Reprod Biol Endocrinol 2009;7:122.

23 Postovit LM, Margaryan NV, Seftor EA, Kirschmann DA, Lipavsky A, Wheaton WW, Abbott DE, Seftor RE, Hendrix MJ: Human embryonic stem cell microenvironment suppresses the tumorigenic phenotype of aggressive cancer cells. Proc Nat Acad Sci USA 2008;105:4329-4334.

24 Saito A, Ochiai H, Okada S, Miyata N, Azuma T: Suppression of lefty expression in induced pluripotent cancer cells. FASEB J 2013;27:2165-2174.

25 Hendrix MJ, Seftor EA, Seftor RE, Kasemeier-Kulesa J, Kulesa PM, Postovit LM: Reprogramming metastatic tumour cells with embryonic microenvironments. Nat Rev Cancer 2007;7:246-255.

26 Park KS: Tgf-beta family signaling in embryonic stem cells. Int J Stem Cells 2011;4:18-23.

27 Miyata N, Azuma T, Hozawa S, Higuchi H, Yokoyama A, Kabashima A, Igarashi T, Saeki K, Hibi T: Transforming growth factor beta and ras/mek/erk signaling regulate the expression level of a novel tumor suppressor lefty. Pancreas 2012;41:745-752.

28 Naidu DG, Tang M, Tabibzadeh S: Lefty peptides, derived by mmp2 cleavage, act as a new class of gelatinase a inhibitor. Front Biosci 2008;13:7193-7201.

29 Sun G, Shi L, Li M, Jiang N, Fu L, Guo J: Lefty inhibits glioma growth by suppressing nodal-activated smad and erk1/2 pathways. J Neurol Sci 2014;347:137-142. 


\section{Cellular Physiology Cell Physiol Biochem 2016;39:815-826

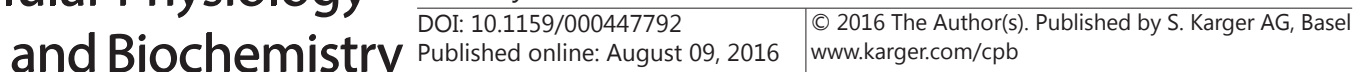 \\ Alowayed et al.: Lefty2 Sensitive Endometrial Cancer Cell Migration}

30 Scholzen T, Gerdes J: The ki-67 protein: From the known and the unknown. J Cell Physiol 2000;182:311322.

31 Li Y, Zhang J, Fang L, Luo P, Peng J, Du X: Lefty a attenuates the tgf-beta1-induced epithelial to mesenchymal transition of human renal proximal epithelial tubular cells. Mol Cell Biochem 2010;339:263-270.

32 Angelucci A, Bologna M: Targeting vascular cell migration as a strategy for blocking angiogenesis: The central role of focal adhesion protein tyrosine kinase family. Curr Pharm Des 2007;13:2129-2145.

33 Cox BD, Natarajan M, Stettner MR, Gladson CL: New concepts regarding focal adhesion kinase promotion of cell migration and proliferation. J Cell Biochem 2006;99:35-52.

34 Nikolic M: The molecular mystery of neuronal migration: Fak and cdk5. Trends Cell Biol 2004;14:1-5.

35 Schaller MD: Fak and paxillin: Regulators of n-cadherin adhesion and inhibitors of cell migration? The J Cell Biol 2004;166:157-159.

36 Zhao X, Guan JL: Focal adhesion kinase and its signaling pathways in cell migration and angiogenesis. Adv Drug Deliv Rev 2011;63:610-615.

37 van Nimwegen MJ, van de Water B: Focal adhesion kinase: A potential target in cancer therapy. Biochem Pharmacol 2007;73:597-609.

38 Ilic D, Furuta Y, Kanazawa S, Takeda N, Sobue K, Nakatsuji N, Nomura S, Fujimoto J, Okada M, Yamamoto T: Reduced cell motility and enhanced focal adhesion contact formation in cells from fak-deficient mice. Nature 1995;377:539-544.

39 Tai YL, Chen LC, Shen TL: Emerging roles of focal adhesion kinase in cancer. Biomed Res Int 2015;2015:690690.

40 Canel M, Serrels A, Frame MC, Brunton VG: E-cadherin-integrin crosstalk in cancer invasion and metastasis. J Cell Sci 2013;126:393-401.

41 Asakura T, Yamaguchi N, Ohkawa K, Yoshida K: Proteasome inhibitor-resistant cells cause emt-induction via suppression of e-cadherin by mir-200 and zeb1. Int J Oncol 2015;46:2251-2260.

42 Becker LE, Takwi AA, Lu Z, Li Y: The role of mir-200a in mammalian epithelial cell transformation. Carcinogenesis 2015;36:2-12.

43 Hata H, Holinka CF, Pahuja SL, Hochberg RB, Kuramoto H, Gurpide E: Estradiol metabolism in ishikawa endometrial cancer cells. J Steroid Biochem 1987;26:699-704.

44 Schmidt S, Schneider S, Yang W, Liu G, Schmidt EM, Schmid E, Mia S, Brucker S, Stournaras C, Wallwiener D, Brosens JJ, Lang F: Tgfbeta1 and sgk1-sensitive store-operated ca2+ entry and orai1 expression in endometrial ishikawa cells. Mol Hum Reprod 2014;20:139-147.

45 Salker MS, Nautiyal J, Steel JH, Webster Z, Sucurovic S, Nicou M, Singh Y, Lucas ES, Murakami K, Chan YW, James S, Abdallah Y, Christian M, Croy BA, Mulac-Jericevic B, Quenby S, Brosens JJ: Disordered il-33/st2 activation in decidualizing stromal cells prolongs uterine receptivity in women with recurrent pregnancy loss. PloS one 2012;7:e52252.

46 Singh Y, Kaul V, Mehra A, Chatterjee S, Tousif S, Dwivedi VP, Suar M, Van Kaer L, Bishai WR, Das G: Mycobacterium tuberculosis controls microrna-99b (mir-99b) expression in infected murine dendritic cells to modulate host immunity. J Biol Chem 2013;288:5056-5061.

47 Voelkl J, Pasham V, Ahmed MS, Walker B, Szteyn K, Kuhl D, Metzler B, Alesutan I, Lang F: Sgk1-dependent stimulation of cardiac na+/h+ exchanger nhe1 by dexamethasone. Cell Physiol Biocehn 2013;32:25-38.

48 Liang CC, Park AY, Guan JL: In vitro scratch assay: A convenient and inexpensive method for analysis of cell migration in vitro. Nat Protoc 2007;2:329-333.

49 Hao H, Naomoto Y, Bao X, Watanabe N, Sakurama K, Noma K, Motoki T, Tomono Y, Fukazawa T, Shirakawa Y, Yamatsuji T, Matsuoka J, Wang ZG, Takaoka M: Focal adhesion kinase as potential target for cancer therapy (review). Oncol Rep 2009;22:973-979.

50 Aplin AE, Juliano RL: Integrin and cytoskeletal regulation of growth factor signaling to the map kinase pathway. J Cell Sci 1999;112:695-706.

51 Alesutan I, Seifert J, Pakladok T, Rheinlaender J, Lebedeva A, Towhid ST, Stournaras C, Voelkl J, Schaffer TE, Lang F: Chorein sensitivity of actin polymerization, cell shape and mechanical stiffness of vascular endothelial cells. Cell Physiol Biochem 2013;32:728-742.

52 Koukouritaki SB, Gravanis A, Stournaras C: Tyrosine phosphorylation of focal adhesion kinase and paxillin regulates the signaling mechanism of the rapid nongenomic action of dexamethasone on actin cytoskeleton. Mol Med 1999;5:731-742. 


\section{Cellular Physiology Cell Physiol Biochem 2016;39:815-826 \begin{tabular}{l|l|l|}
\hline DOI: 10.1159/000447792 & $\begin{array}{l}\text { C) 2016 The Author(s). Published by S. Karger AG, Basel } \\
\text { www.karger.com/cpb }\end{array}$
\end{tabular} \\ Alowayed et al.: Lefty2 Sensitive Endometrial Cancer Cell Migration}

53 Chen HC, Appeddu PA, Isoda H, Guan JL: Phosphorylation of tyrosine 397 in focal adhesion kinase is required for binding phosphatidylinositol 3-kinase. J Biol Chem 1996;271:26329-26334.

54 Gu S, Kounenidakis M, Schmidt EM, Deshpande D, Alkahtani S, Alarifi S, Foller M, Alevizopoulos K, Lang F, Stournaras C: Rapid activation of fak/mtor/p70s6k/pak1-signaling controls the early testosteroneinduced actin reorganization in colon cancer cells. Cell Signal 2013;25:66-73.

55 Yin HL, Janmey PA: Phosphoinositide regulation of the actin cytoskeleton. Annu Rev Physiol 2003;65:761789.

56 Manser E, Huang HY, Loo TH, Chen XQ Dong JM, Leung T, Lim L: Expression of constitutively active alphapak reveals effects of the kinase on actin and focal complexes. Mol Cell Biol 1997;17:1129-1143.

57 Manser E, Leung T, Salihuddin H, Zhao ZS, Lim L: A brain serine/threonine protein kinase activated by cdc42 and rac1. Nature 1994;367:40-46.

58 Ilic D, Mao-Qiang M, Crumrine D, Dolganov G, Larocque N, Xu P, Demerjian M, Brown BE, Lim ST, Ossovskaya V, Schlaepfer DD, Fisher SJ, Feingold KR, Elias PM, Mauro TM: Focal adhesion kinase controls ph-dependent epidermal barrier homeostasis by regulating actin-directed na $/ \mathrm{h}+$ exchanger 1 plasma membrane localization. Am J Pathol 2007;170:2055-2067.

59 Tominaga T, Barber DL: Na-h exchange acts downstream of rhoa to regulate integrin-induced cell adhesion and spreading. Mol Biol Cell 1998;9:2287-2303.

60 Fabry B, Klemm AH, Kienle S, Schaffer TE, Goldmann WH: Focal adhesion kinase stabilizes the cytoskeleton. Biophys J 2011;101:2131-2138.

61 Raftopoulou M, Hall A: Cell migration: Rho gtpases lead the way. Dev Biol 2004;265:23-32.

62 Webb DJ, Donais K, Whitmore LA, Thomas SM, Turner CE, Parsons JT, Horwitz AF: Fak-src signalling through paxillin, erk and mlck regulates adhesion disassembly. Nat Cell Biol 2004;6:154-161.

63 Chen BH, Tzen JT, Bresnick AR, Chen HC: Roles of rho-associated kinase and myosin light chain kinase in morphological and migratory defects of focal adhesion kinase-null cells. J Biol Chem 2002;277:3385733863.

64 Yoon H, Dehart JP, Murphy JM, Lim ST: Understanding the roles of fak in cancer: Inhibitors, genetic models, and new insights. J Histochem Cytochem 2015;63:114-128.

65 Salker MS, Schierbaum, Alowayed N, Singh Y, Mack AF, Stournaras C, Schäffer T, Lang F: Leftya decreases actin polymerization and stiffness in human endometrial cancer cells. Sci Rep 2016;6:29370. doi: 10.1038/ srep29370.

66 Ho JN, Jun W, Choue R, Lee J: I3c and icz inhibit migration by suppressing the emt process and fak expression in breast cancer cells. Molr Med Rep 2013;7:384-388.

67 Kiefel H, Bondong S, Pfeifer M, Schirmer U, Erbe-Hoffmann N, Schafer H, Sebens S, Altevogt P: Emtassociated up-regulation of $11 \mathrm{cam}$ provides insights into l1 cam-mediated integrin signalling and nf-kappab activation. Carcinogenesis 2012;33:1919-1929.

68 Taliaferro-Smith L, Oberlick E, Liu T, McGlothen T, Alcaide T, Tobin R, Donnelly S, Commander R, Kline E, Nagaraju GP, Havel L, Marcus A, Nahta R, O'Regan R: Fak activation is required for igf1r-mediated regulation of emt, migration, and invasion in mesenchymal triple negative breast cancer cells. Oncotarget 2015;6:4757-4772.

69 Wilson C, Nicholes K, Bustos D, Lin E, Song Q, Stephan JP, Kirkpatrick DS, Settleman J: Overcoming emtassociated resistance to anti-cancer drugs via src/fak pathway inhibition. Oncotarget 2014;5:7328-7341.

70 Zhang L, Li Z, Fan Y, Li H, Li Z, Li Y: Overexpressed grp78 affects emt and cell-matrix adhesion via autocrine tgf-beta/smad2/3 signaling. Int J Biochem Cell Biol 2015;64:202-211.

71 Zhang P, Bai H, Liu G, Wang H, Chen F, Zhang B, Zeng P, Wu C, Peng C, Huang C, Song Y, Song E: Microrna33b, upregulated by ef24, a curcumin analog, suppresses the epithelial-to-mesenchymal transition (emt) and migratory potential of melanoma cells by targeting hmga2. Toxicol Lett 2015;234:151-161.

72 Livasy CA, Moore D, Cance WG, Lininger RA: Focal adhesion kinase overexpression in endometrial neoplasia. Appl Immunohistochem Mol Morphol 2004;12:342-345.

73 Stokes JB, Adair SJ, Slack-Davis JK, Walters DM, Tilghman RW, Hershey ED, Lowrey B, Thomas KS, Bouton AH, Hwang RF, Stelow EB, Parsons JT, Bauer TW: Inhibition of focal adhesion kinase by pf-562,271 inhibits the growth and metastasis of pancreatic cancer concomitant with altering the tumor microenvironment. Mol Cancer Ther 2011;10:2135-2145.

74 Mitra SK, Hanson DA, Schlaepfer DD: Focal adhesion kinase: In command and control of cell motility. Nat Rev Mol Cell Biol 2005;6:56-68. 


\section{Cellular Physiology Cell Physiol Biochem 2016;39:815-826 \begin{tabular}{l|l|l} 
DOI: 10.1159/000447792 & and Biochemistry & $\begin{array}{l}\text { O 2016 The Author(s). Published by S. Karger AG, Basel } \\
\text { www.karger.com/cpb }\end{array}$
\end{tabular} \\ Alowayed et al.: Lefty2 Sensitive Endometrial Cancer Cell Migration}

75 Korpal M, Lee ES, Hu G, Kang Y: The mir-200 family inhibits epithelial-mesenchymal transition and cancer cell migration by direct targeting of e-cadherin transcriptional repressors zeb1 and zeb2. J Biol Chem 2008;283:14910-14914.

76 Park SM, Gaur AB, Lengyel E, Peter ME: The mir-200 family determines the epithelial phenotype of cancer cells by targeting the e-cadherin repressors zeb1 and zeb2. Genes Dev 2008;22:894-907.

77 Salker MS, Zhou Y, Singh Y, Brosens J, Lang F: Leftya sensitive cytosolic ph regulation and glycolytic flux in ishikawa human endometrial cancer cells. Biochem Biophys Res Commun 2015;460:845-849.

78 Czepan M, Rakonczay Z, Jr., Varro A, Steele I, Dimaline R, Lertkowit N, Lonovics J, Schnur A, Biczo G, Geisz A, Lazar G, Simonka Z, Venglovecz V, Wittmann T, Hegyi P: Nhe1 activity contributes to migration and is necessary for proliferation of human gastric myofibroblasts. Pflugers Arch 2012;463:459-475.

79 Park JH, Ryu JM, Yun SP, Kim MO, Han HJ: Fibronectin stimulates migration through lipid raft dependent nhe-1 activation in mouse embryonic stem cells: Involvement of rhoa, ca(2+)/cam, and erk. Biochim Biophys Acta 2012;1820:1618-1627.

80 Schwab A, Rossmann H, Klein M, Dieterich P, Gassner B, Neff C, Stock C, Seidler U: Functional role of na+hco3- cotransport in migration of transformed renal epithelial cells. J Physiol 2005;568:445-458.

81 Shi Y, Yuan H, Kim D, Chanana V, Baba A, Matsuda T, Cengiz P, Ferrazzano P, Sun D: Stimulation of $\mathrm{na}(+) / \mathrm{h}(+)$ exchanger isoform 1 promotes microglial migration. PloS one 2013;8:e74201.

82 Stock C, Gassner B, Hauck CR, Arnold H, Mally S, Eble JA, Dieterich P, Schwab A: Migration of human melanoma cells depends on extracellular ph and na+/h+ exchange. J Physiol 2005;567:225-238.

83 Wu D, Doods H, Stassen JM: Inhibition of human pulmonary artery smooth muscle cell proliferation and migration by sabiporide, a new specific nhe-1 inhibitor. J Cardiovasc Pharmacol 2006;48:34-40.

84 Zolota Z, Koliakos G, Paletas K, Kaloyianni M: Nhe-1 and beta1 integrin dependent monocyte adhesion and migration after glucose, insulin or ppargamma stimulation. Cell Adh Migr 2011;5:258-265.

85 Gu S, Papadopoulou N, Nasir O, Foller M, Alevizopoulos K, Lang F, Stournaras C: Activation of membrane androgen receptors in colon cancer inhibits the prosurvival signals akt/bad in vitro and in vivo and blocks migration via vinculin/actin signaling. Mol Med 2011;17:48-58. 